\title{
DANGE, FILM, AND THE BALLETS RUSSES
}

\author{
Lynn Garafola
}

On 29 December 1921, as The Sleeping Princess entered the second month of its run at London's Alhambra Theatre, The Times announced that a plan was afoot to film the ballet. Amazingly, the initiative came from the inveterately anti-populist Diaghilev himself. Impressed by the film version of The Three Musketeers that Walter Wanger was then producing at Covent Garden to music 'synchronised' by conductor Eugene Goosens, Diaghilev had come to the conclusion 'that the same method might be applied to bring about the more general appreciation of classical ballet'. 'It has [also] been suggested,' continued The Times, 'that the film be done "in natural colours in the same way as The Glorious Adventure, the next production to be shown at Covent Garden [and] the first British film of the kind to be carried out in colours. In this way the glories of M. Bakst's costumes would not be lost, and the whole action of the ballet would be materially assisted.' The scheme, as indicated by a follow-up article, was part of a larger undertaking to 'produce original films built up on original musical scores and on the scores of a number of existing operas'. The artistic side was entrusted to motion picture newcomers - the painters Augustus John and S. H. Sime, who were to 'concern themselves with the settings', and the composer Josef Holbrooke, who was to 'provide much of the music'. In other words, the plan was intended to appropriate the 'cheap and rapidly breeding cinema', in T. S. Eliot's words, ${ }^{3}$ for the purposes of 'high art', the reason Diaghilev would have entertained the idea in the first place.

Neither The Sleeping Princess nor any other Ballets Russes production was ever filmed. Yet the cinema, which came of artistic age during the life span of the company, shadowed virtually every stage of its development. Diaghilev himself, with his deep-seated mistrust of mass culture and its allied forms of mechanical reproduction, had little use for film: in his mind, it belonged to the world of popular entertainment - to the music halls, for instance, where,

This is the original English of an article first published in German translation in Spiegelungen: Die Ballets Russes und die Künst, ed. Claudia Jeschke, Ursel Berg, and Birgit Zeidler (Berlin: Verlay Vorwerk 8, 1997), pp. 164-85. 
by the late 1890s, biographs and 'cinématographes' were sharing bills with clowns, acrobats, singers, mimes, comedians, cyclists, instrumentalists, and dancers of every variety, including ballet. Just as in his early days as an impresario he insisted on identifying his company exclusively with 'high art' venues and audiences and dissociating it from the 'popular' ballet tradition linked to music hall and spectacle shows, so he took pains throughout his career to restrict the use of film and cinematic borrowings. Indeed, in almost every instance where they do appear in Ballets Russes productions, they had already undergone an aestheticising process that at least partly transformed their original identity and gave them currency as high art. At the same time, especially during the pre-World War I period, there are parallels between the two media that suggest the existence of a common source on which film and ballet equally drew, while in the years that immediately followed, film drew on approaches associated with the ballet stage and, in Russia especially, ideas put into currency by the 'new dance'. The rebirth of twentieth-century ballet coincided with the birth of film as an art form: never again would the two media be so close as during that period of genesis.

In 1914, Michel Fokine laid out the principles of his 'new ballet' in an article published in the letter columns of The Times. Although the cinema is nowhere mentioned, his 'rules' suggest a number of parallels between the 'new ballet' and film. One is the emphasis on naturalism. 'Dancing and mimetic gesture,' he stated,

have no meaning in a ballet unless they serve as an expression of its dramatic action. ... [T] he new ballet admits the use of conventional gesture only where it is required by the style of the ballet, and in all other cases endeavours to replace gestures of the hands by [a] mimetic of the whole body. Man can be and should be expressive from head to foot. ${ }^{4}$

Fokine's revolt against the stylised pantomime and 'conventional system of gesticulation' of the 'old ballet' and his insistence that they be replaced by a more natural style of acting paralleled the changes in acting on the drama stage of the immediately preceding decades while coinciding with the requirements of silent screen acting. The contrast between the gestural histrionics of Sarah Bernhardt and the infinitely more subtle mimetic effects of Eleanora Duse - both preserved on film - sums up this shift, while revealing the obvious superiority of Duse's approach in exploiting the possibilities of the new medium. 
Fokine's embrace of naturalism almost certainly had its source in the psychological realism of the Moscow Art Theatre. He was in the audience for its first performances in St. Petersburg, and must have viewed its evocative reconstructions of character and place, especially in its performances of Chekhov, as a thrilling alternative to acting on the ballet stage, which, as he wrote in 1916, 'essayed to express a psychological feeling by a fixed movement, or series of movements, which could neither describe nor symbolise anything'. ${ }^{5}$ The dancers formed under his aegis - Vaslav Nijinsky, Anna Pavlova, Tamara Karsavina, to name only the most celebrated - were all superb dancer-actors who changed personalities with their roles, 'subordinat[ing]', as Pavlova explained it, the 'physical elements to a psychological concept'.

In this process, rhythmic gesture played a crucial role. To be sure, as an action performed in time and generally to music, all dance gesture is in some measure rhythmic. However, where conventional ballet mime gestures were fixed in meaning and shape, Fokine's 'expressive signs' were open-ended: their form varied, and they acquired meaning from the musical and dramatic contexts in which they appeared. In this sense, they closely resembled the 'choreographed' gesture of silent film, where, as in the 'new ballet', physical expressiveness was at a premium. Although the conventionalised gestures of a Bernhardt might enhance the words they accompanied, they could not make up for the absence of speech. As much as the 'new ballet', then, the silent screen called for actors who embodied Fokine's 'mimetic of the whole body'. Discussing the progressive tendency of modern choreography to 'eliminate the artificial dividing line between dancing and mime', the British music critic Edwin Evans insisted in The Dancing Times that the 'point of intersection' between ballet and cinema lay in the 'art of rhythmic movement ... one and indivisible'. 'Serafima Astafieva, a former Diaghilev dancer, described the connection between the two media even more succinctly. 'The cinema is mime,' she told readers of the magazine in $1917 .^{\circ}$

No wonder so many early Ballets Russes dancers were tempted by the cinema. In 1919, ten years after she had dazzled Paris audiences in the title role of Cléopâtre, Ida Rubinstein appeared as the exotic heroine of $L a$ Nave, a screen version of Gabriele d'Annunzio's play directed by his son. In 1921, at the height of her fame, Karsavina played a Belle Epoque Parisian dancer in a film 


\section{DANGE RESEARGH}

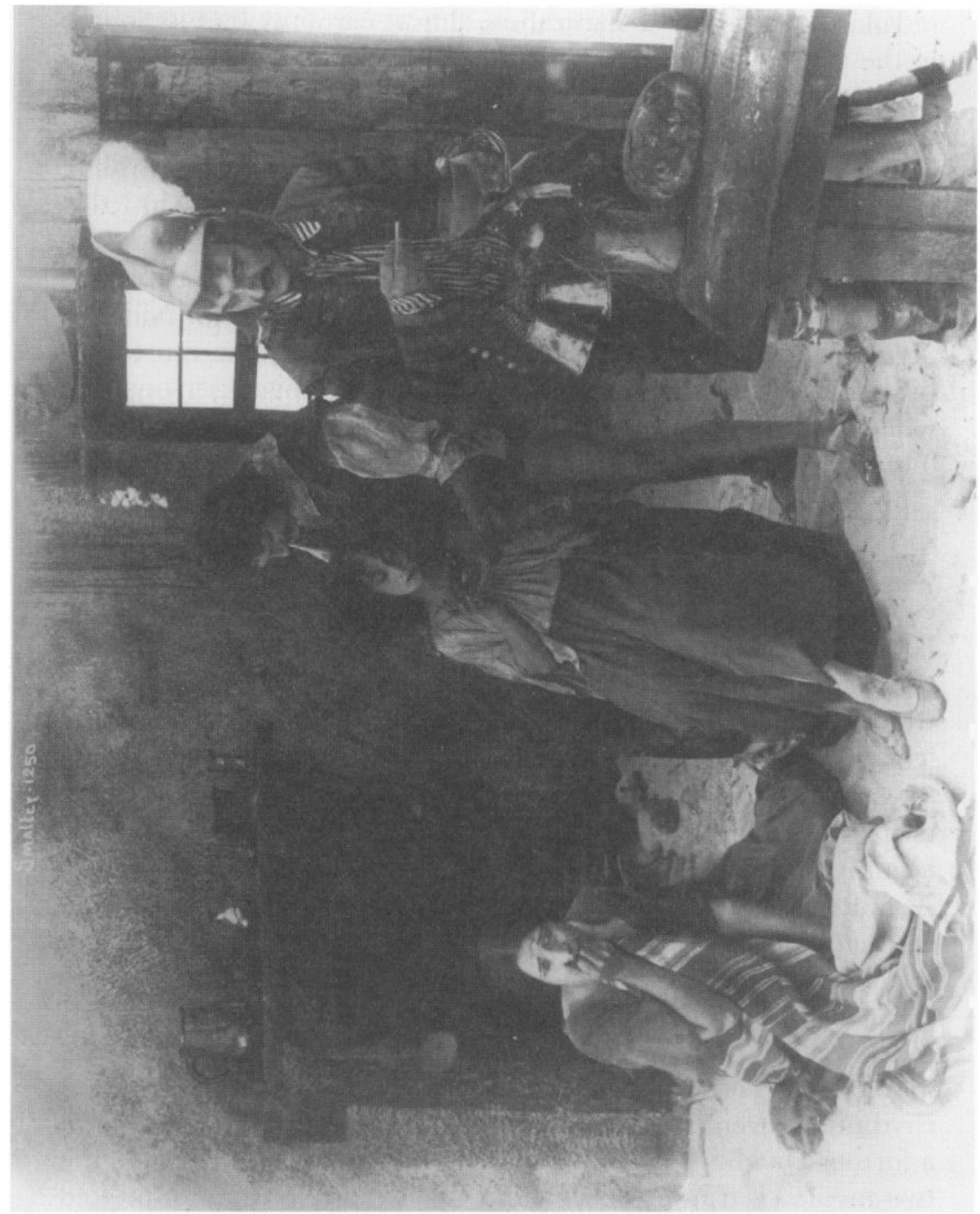

Fig. 1. Anna Pavlova in a scene from the film The Dumb Girl of Portici (Pritchard Collection) 
dramatisation of Arnold Bennett's The Old Wives Tale. Ever a pioneer, Anna Pavlova had taken the plunge six years earlier, appearing as Fenella in a cinematic version of the Auber opera The Dumb Girl of Portici. In this 'straight' dramatic role (augmented with dances to satisfy her fans), she displayed the rhythmic subtlety, gestural expressiveness, and luminous facial expression of an ideal Fokine dancer who was equally at home in the new medium. Another fascinating experiment by a Diaghilev star was The Dance of Death, a film of Adolph Bolm's ballet Danse Macabre produced in 1922 by Dudley Murphy. (Two years later Murphy collaborated with the painter Fernand Léger on Le Ballet mécanique, one of the earliest abstract films.) The first in a projected series of twelve 'visual symphonies' - filmed dance interpretations of classical music - The Dance of Death was advertised as the first dance film to be synchronised with a sound score. ${ }^{9}$

The roster of Diaghilev's early seasons also included two dancers who eventually made long-term careers in film. One was Vera Karalli, a protégée of the Bolshoi choreographer Alexander Gorsky, who became one of the Russian cinema's first silent screen stars. Like Fokine, Gorsky had fallen under the sway of the Moscow Art Theatre, and during the years he directed the Bolshoi company, he formed a brilliant constellation of dancer-actors. A dark-haired beauty, Karalli had the plasticity that Gorsky prized highly in his dancers, and he cast her in works, such as $\mathcal{N u r}$ and Anitra, influenced by the 'free' dance style of Isadora Duncan. Her screen credits included Do You Remember?, Chrysanthemums, War and Peace (in which she played the role of Natasha), and The Dying Swan. In Chrysanthemums she performed a Duncan-style dance - choreographed in all likelihood by Gorsky - that ended with her dying on a bed of flowers. ${ }^{10}$

Even more amazing was the film career of Theodore Kosloff, another Bolshoi dancer who came to the fore under Gorsky. Kosloff left the Ballets Russes after the first season, long enough to 'steal' Fokine's choreography of Cléopâtre and Les Sylphides, which, along with Schéhérazade, he restaged in New York for Gertrude Hoffmann's 'Saison Russe'. Eventually, he made his way to Hollywood and in 1917 went to work for Cecil B. DeMille. His screen debut as the Aztec leader Guatemoc in The Woman God Forgot was the first of many 'exotic' roles he played as a member of DeMille's repertory company. 'When I first saw Kosloff,' wrote 
DANGE RESEARGH
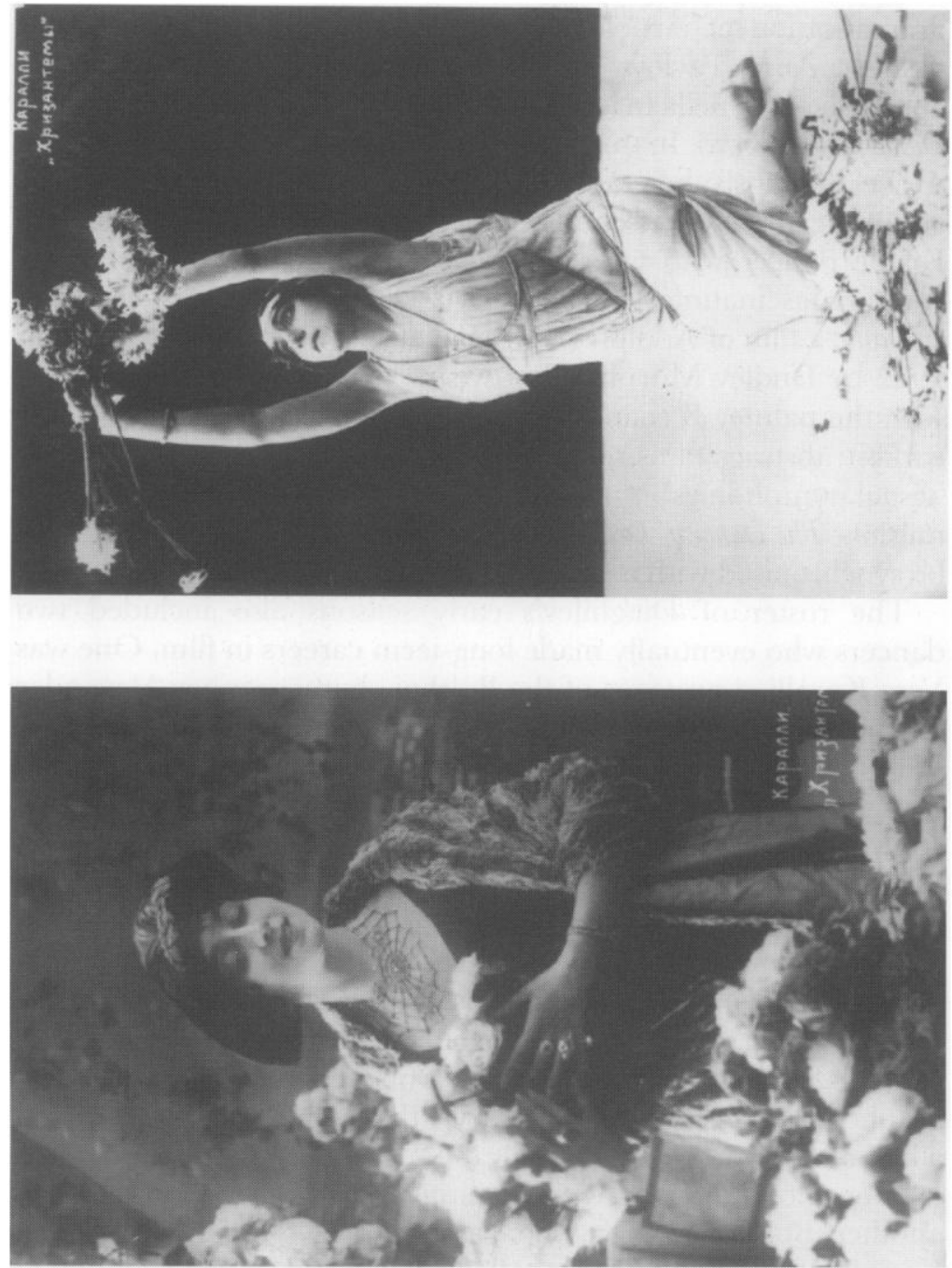

Figs. 2 and 3. Vera Karalli as Vera Alekseyeva Nevolina, ballerina, in Chrysanthemums or the Tragedy of a Ballerina directed by Petr Chardynin, 1914 
the director's niece Agnes de Mille of her future teacher,

he was naked in feathers, leaning on a feathered spear. He had painted himself horned eyebrows in the Russian Ballet style, and his gestures were real classic pantomime, involving clenched fists and the whites of the eyeballs, a positive style which gave the camera something substantial to focus on. Here was passion and here certainly was sincerity in amounts. Every expression was performed with a force that could have carried him across the room and over the wall. I was awe-struck."

During the 1920s Kosloff was involved in almost every film DeMille made. He served in many capacities - actor, dancer, choreographer, technical art director, and unofficial advisor. A close friend of the director, Kosloff also acted as an aide-de-camp in staging the huge crowd scenes, often in the form of flashbacks and supplied with extras from his school, that were a trademark of DeMille's films. With their exotic backgrounds (ancient Babylonia in Why Change Your Wife?, ancient Rome in Manslaughter, ancient Palestine in The King of Kings) and fantastic orgies (the jazz dance in Saturday Night took place in a swimming pool), these scenes recalled not only the bacchanalias of Fokine's Cléopâtre and Schéhérazade but also the spectacular crowds of Gorsky's productions at the Bolshoi, especially Don Quixote and Salammbô, in which Kosloff had also danced. ${ }^{12}$ Like Fokine's dances for the 'Oriental' extravaganzas Aphrodite and Mecca, his first major commissions in the United States, ${ }^{13}$ Kosloff's film work plundered an earlier style of European 'high art' to entertain the American masses. ${ }^{14}$

Although Kosloff's career, like Karalli's, reveals a direct link between the new dance and film, it was Russia's theatrical culture that served as the major transmission point between the two media. Even before the 1910s, when choreography became what film scholar Mikhail Yampolsky has called 'a metamodel for the performing arts', ${ }^{15}$ the Moscow Art Theatre offered classes in expressive movement. Initially taught by Mikhail Mordkin, a Gorsky protégé, they were later taken over by Eli Kniepper (Rabanek), one of Duncan's early Russian followers: among her students was Alisa Koonen, who became a leading actress of Alexander Tairov's Kamerny Theatre. ${ }^{16}$ At St. Petersburg's Antique Theatre, co-founded by Nikolai Evreinov in 1907, the dances were confided initially to Fokine and subsequently to Valentin Presniakov, a Maryinsky and sometime Ballets Russes colleague who also taught classes to the actors in 'plastique'. ${ }^{17}$ 
Dance figured prominently in Evreinov's Crooked Mirror Theatre, which offered hilarious parodies of Giselle, Swan Lake, and Esmeralda and impersonations en travesti of Duncan and Maud Allan by the company's in-house 'ballerina' Nikolai Barabanov. ${ }^{18}$ At the Liteiny Theatre, another artists' cabaret, Boris Romanov choreographed The Goatlegged, a ballet that satirised the bacchanalia of Fokine's Daphnis and Chloe and had Anna Akhmatova's innamorata, Olga Glebova Sudeikina, as its sensational star. ${ }^{19}$ Romanov also staged dances with 'a touch of an orgiastic bouquet' (as Akim Volynsky later wrote) at another bohemian cabaret, the Stray Dog, where Karsavina herself occasionally performed. ${ }^{20}$

According to the choreographer Lasar Galpern, who served as ballet master and teacher of gesture at Moscow's Jewish State Theatre from 1919 to 1923 and staged the first German Rite of Spring in 1930, it was Tairov who 'first ... made his actors real dancers'. ${ }^{21}$ Movement played an extensive part in Tairov's productions: indeed, on the Kamerny stage, as John E. Bowlt has observed, 'theatre once again became a kinetic rather than a literary or decorative experience' ${ }^{22}$ Several of his actors had dance training - Koonen, Alexander Rumnev (who may have studied with Mordkin), ${ }^{23}$ and Vera de Bosset (later Stravinsky), who had studied ballet at Lydia Nelidova's Moscow studio and later played the role of the Queen in Diaghilev's Sleeping Princess. While acting with Tairov, she became a well-known film actress, appearing in War and Peace and starring in a number of comedies opposite one of the sons of Marius Petipa. ${ }^{24}$

Tairov, in fact, was deeply enamoured of ballet. He admired Pavlova, adopted much from Fokine, and had worked with Boris Romanov. In a 1921 article he called ballet dancers 'the only actors in contemporary theatre who understand the significance of the corporeal in our art'. ${ }^{25}$ His productions, theatre historian Konstantin Rudnitsky has observed, emphasised a 'balletic coordination of movements', 'beauty and purity of pose and gesture', and a 'balletic method of organising space', which 'allowed the actors to demonstrate ... their physical virtuosity'. When rehearsing Koonen in the title role of Sakuntala, Tairov advised her to study Duncan, explaining that in her dancing 'there is a kind of earthly gravitation which seems to make the gesture heavier, creating its volume'. ${ }^{26}$ In Famira Kifared, where he gave much thought to equalising the status of body movement and speech, 'the lightness 
and ease of the theatrical language', notes Rudnitsky, 'was accompanied by a slow heaviness of movement and the deep, guttural singing by the tense excitement of the dance'. ${ }^{27}$ And he confided the design of this and other key productions to Alexandra Exter, whose interest in " "rhythmically organised space' pointed forward", as John Bowlt has said, "to her Constructivist designs for the movie Aelita, ${ }^{28}$ even as it coincided with the initial stage of her collaboration with choreographer Bronislava Nijinska. ${ }^{29}$

Meyerhold, too, viewed movement as integral to the stage, although, unlike Tairov, he had little use for ballet as such. Nevertheless, many of his experiments, from the slow, 'signifying' movement, 'inner rhythm', and 'sculptural expressiveness' of his symbolist phase, to the use of commedia dell'arte devices in his studio work, and the 'études' that were the embryo of his later system of biomechanics, resonated with certain aspects of Ballets Russes productions. ${ }^{30}$ If anything, the post-Revolutionary development of biomechanics only enhanced the importance of rhythm. 'Through biomechanics,' writes Rudinitsky, 'Meyerhold turned rhythm into a component of the performance which created form and also gave it content. The rhythmic organisation of a role entailed the impulsive reflexive link between thought and movement, emotion and movement, speech and movement. ... Every movement, whether ... intended ... or not, acquired sculptural form and significance. ${ }^{31}$ As a disciple of Meyerhold in this period, Sergei Eisenstein absorbed these ideas, which not only found their way into his early films but were also directly connected to his experience of dance. Recalling his foxtrot lessons with Valentin Parnakh in 1921, he wrote: 'in contradistinction to the dances of my youth, with their strictly prescribed patterns and rotation of movement, the foxtrot was a "free dance", held together only by a strict rhythm, on the framework of which one could embroider any freely improvised movement. ... Here ... [was] that captivating free running line, subordinated only to the inner law of rhythm. ${ }^{32}$

Dance also figured prominently in Lev Kuleshov's theory and practice of montage. Like many pioneering Russo-Soviet filmmakers, he was deeply interested in Delsartian theories of gesture and Dalcrozian ideas of rhythm, especially as these were reinterpreted in the 1910s by Prince Sergei Volkonsky, the former director of the Imperial Theatres under whom Diaghilev had briefly served. Volkonsky himself taught briefly at the First State Cinema 
School, which was set up after the Revolution by Vladimir Gardin, as did Kuleshov and Nikolai Foregger, known in the 1920s for his 'machine dances'. The school maintained close ties with the Experimental Heroic Theatre directed by Boris Ferdinandov, who had developed a Dalcrozian-inspired system known as 'metrorhythm'. Kuleshov was especially close to this group, and two of his earliest montage experiments involved dance. 'The question of dance,' wrote Valentin Turkin in 1925,

has a special significance for contemporary cinema and, in particular, for the mastery of film acting. The search for strict artistic form in cinema is moving towards the measured construction of the actor's movement on the screen and of the rhythmic montage of the film, i.e., towards the creation from the movement on the screen of a kind of 'dance'. ... Film drama is trying to immerse itself in the culture of dance, in rhythm, so that it actually becomes 'dance', a sort of contemporary, realistic or, if you prefer, analytical or biomechanical ballet. ${ }^{33}$

For all the crossovers and parallels linking dance and film during the early years of the Ballets Russes, the cinema left no discernible mark on the company's aesthetic. With the First World War, this ceased to be the case. Diaghilev's discovery of the Italian futurists and his embracing of Cocteau's 'poetry of the everyday' prompted a sea change in his attitude toward film, which now made its appearance in Ballets Russes productions as a sign of modernity and as a choreographic strategy.

In September 1916, accompanied by choreographer Léonide Massine and a skeleton company of dancers, Diaghilev settled in Rome. By the following winter, three works were on the way - The Good-Humoured Ladies, Fireworks, and Parade - in which the influence of film was palpable. In Rome, Diaghilev renewed his contacts with the futurists that the company's American tour had interrupted. The year 1916 was a productive one for futurist cinema. No fewer than four futurist or futurist-inspired films were made that year - Vita futurista, Il perfido incanto, Thais, and Il mio cadavere. Of these, the most important for the Ballets Russes was Vita futurista, which involved several artists close to Diaghilev, including Filippo Marinetti, with whom he had briefly entertained the possibility of an 'alliance', ${ }^{34}$ and Giacomo Balla, who would design the set and lighting design of Fireworks.

Another futurist with an interest in cinema whom Diaghilev 
commissioned in this period was Fortunato Depero, ${ }^{35}$ 'It is necessary,' Depero asserted in his 1916 manifesto 'Notes on the Theatre', 'to add to theatre everything that is suggested by cinematography.' 'Why does cinematography triumph?,' he asked. 'It wins because it is fast, because it moves and transforms rapidly, ... is varied and rich, improvised, and surprising. ... Cinematography, removed from the assassin's hands of certain reconstructors of historical dramas ... and of melancholy makers of banal human passions ... will become a powerful means of artistic creation. ${ }^{36}$ 'The Futurist Cinema,' a manifesto by Marinetti, Balla, and others published in November 1916, echoed these visionary ideas. The futurist cinema, proclaimed the authors, was 'an alogical fleeting synthesis of life', 'a school of joy, of speed, of force', a 'polyexpressive symphony'. At the same time, they singled out as attributes of the new cinema such techniques as 'simultaneity and interpenetration of different times and places' and 'unreal reconstructions of the human body. ${ }^{37}$

Such ideas left a deep imprint on Massine's developing sensibility as a choreographer. Beginning with The Good-Humoured Ladies, simultaneity and speed became preeminent features of his choreography. In seeming response to the futurist call for the 'interpenetration' of time and place, he compressed Goldoni's play into one act, balancing the action simultaneously on both sides of the stage so as to retain all the complications of the plot. At the same time, he speeded up the dance gesture and used broken, angular movements to distort it; he stressed dynamism through continual movement, and strove for what he called a 'synthesis of movement and form' or 'choreography and plastic art' ${ }^{38} \mathrm{He}$ was fascinated by Charlie Chaplin and gave Niccolo, the waiter in Ladies, a 'whimsical side-way shuffle' (as Cyril W. Beaumont described it ${ }^{39}$ that recalled the star's distinctive gait. And it was in Rome that Massine bought his first camera. 'I take great interest in cinematography,' he wrote to a Moscow friend, Anatoly Bolchakov. 'I tried to shoot movies, but so far did not succeed. ${ }^{40}$

Of all the works produced by Diaghilev in this period, Fireworks, to Stravinsky's music of the same title, most closely approximated film. Balla's mise-en-scène for this short piece - a light show played on a setting of geometrical solids - epitomised the brevity, dynamism, and abstraction to which futurist theatre aspired. 'He filled 
the stage,' critic Maurizio Fagiolo dell'Arco has written, 'with disturbing crystalline forms, beams of colored light, coral formations, symbols of the infinite (spirals and running light-waves), emblems of light (obelisk, pyramids, rays of sunlight and sickle-moons), aerodynamic symbols (flights of swifts and firebirds). It was all projected onto a black backdrop, illuminated from behind with red rays. ${ }^{41}$ The emphasis on light, the idea of phenomena in constant mutation, and the use of images inspired by the natural world suggest an influence on Balla even more powerful than futurism that of Loie Fuller. Indeed, only a week before the opening of Diaghilev's last prewar season, she had presented her own version of the Stravinsky piece at the Théatre du Châtelet, an 'orgy of color, light, and sound', ${ }^{42}$ deploying, as critic Emile Vuillermoz wrote, 'all her virtuosity and all her inventive genius'. ${ }^{43}$ Although Fuller herself is not mentioned in Depero's 'Notes on the Theatre', her work certainly embodied the 'plastic-magic phenomena' that he espoused in his 'vast re-creation of mimicry'. ${ }^{44}$ Moreover, as Giovanni Lista has pointed out in his recent biography of the dancer, the 'Dance of Geometric Splendor' in Vita futurista was actually an adaptation of Fuller's La Danse de l'acier. ${ }^{45}$ By eliminating the human element, as her Fireworks had not, Diaghilev's chromokinetic experiment achieved the paradoxical status of an abstract film realised through the medium of the stage.

However intriguing this line of experiment may have been, Diaghilev did not pursue it. Indeed, as Bronislava Nijinska later noted, he had little sympathy for ballets 'without libretti'. ${ }^{46} \mathrm{He}$ found abstraction 'foreign', and even in works such as La Chatte or Ode that made use of abstract elements, he insisted upon a libretto detailing the mimetic action. This is not to say that film as such vanished from the Ballets Russes repertory. However, with the exception of Ode (of which more later), its influence was circumscribed: it became a touchstone of the everyday, a sign denoting the pleasures of modern life.

In this, no one proved more influential than Jean Cocteau. His ballet Parade, produced by Diaghilev in 1917, was a paean to what he called the 'music of everyday' - variety, circus, jazz, and cinema. Movies, especially American movies, fascinated him. He loved Westerns, and pictured himself in his letters as living in 'Texas' or 'a corner of the Far West'. ${ }^{47}$ And, like Massine - as well as Diaghilev, for that matter - he adored Chaplin, a 'modern Punch 
[who] speaks to all ages, to all peoples' ${ }^{48}$ Cocteau's notes for the ballet's 'Little American Girl' are full of cinematic allusions, and even those for the Chinese Conjuror, a role partly inspired by the magician Chung Ling Soo, include a reference to the 'silence of thunderous events in silent films'. ${ }^{49}$

Movies were not simply a 'popular resource ${ }^{50}$ in Parade. They were also a cornerstone of the American myth that now made its debut in Cocteau's work. 'The United States,' he wrote in 1919, 'evokes a girl more interested in her health than in her beauty. She swims, boxes, dances, leaps onto moving trains - all without knowing that she is beautiful. It is we who admire her face, on the screen - enormous, like the face of a goddess. ${ }^{, 51}$ Under Cocteau's tutelage, Massine's American Girl evoked the 'reality' of her celluloid counterpart. 'Wearing a blazer and a short white skirt,' the choreographer wrote,

she bounced on to the stage, crossing it in a succession of convulsive leaps, her arms swinging widely. She then did an imitation of the shuffling walk of Charlie Chaplin, followed by a sequence of mimed actions reminiscent of The Perils of Pauline - jumping on to a moving train, swimming across a river, having a running fight at pistol-point, and finally finding herself lost at sea in the tragic sinking of the Titanic. All this was ingeniously danced and mimed by Maria Chabelska who interpreted Satie's syncopated ragtime music with great charm and gusto, and brought the dance to a poignant conclusion when, thinking herself a child at the seaside, she ended up playing in the sand. ${ }^{52}$

Although Parade announced the modernism of Diaghilev's new aesthetic, his artistic 'recipe' for the next several years pointedly excluded Cocteau's 'gentrified' populism. Indeed, between 1917 and 1924, when Le Train Bleu came to the stage, allusions to film and contemporary pastimes in general - were noticeably absent from the Ballets Russes stage. Ironically, it was during these same years that film discovered dance in a big way. In May 1922 the French monthly La Danse commended Pathé-Revue's new weekly feature of the best dances and dancers from leading Paris and foreign theatres. It also praised an 'astonishing' new process - slow motion - that thanks to the Pathé Ultra Rapid Camera, the company had used in dance filming as early as $1919 .{ }^{53}$ (In September of that year, The Dancing Times published a 'specimen' of the new process - a still from 'The Jigg'.) ' $^{54}$ Many writers noted the educational aspect of the new technique, which opened up 'interesting possibilities for analysing and demonstrating dance steps ${ }^{35}$ and 
led one French publishing house to 'shoot ... an entire series of modern dances', with on-screen explanations of how to do them. ${ }^{56}$ Dancing Grace, filmed by Pathé in the early 1920s, shows Lydia Lopokova bounding across a lawn with gravity-defying lightness, a hint at the artistic effects that slow motion could generate. However, it was Loie Fuller, in her 1920 feature-length film Le Lys de la vie, who explored the new technique for poetic ends, creating fleeting, dreamlike images that 'freed' the medium from 'illusionism' and imbued it with fantasy. ${ }^{57}$

Cocteau was fascinated by slow motion. He used it in Le Boeuf sur le toit, presented in 1920 at the Comédie des Champs-Elysées, and in Les Mariés de la Tour Eiffel, produced the following year by the Ballets Suédois. Like freeze framing, another technique borrowed from the cinema, slow motion also appeared in Le Train Bleu, most notably in Scene 5, where the 'tarts' and 'gigolos' at play on a Riviera beach glimpse an airplane passing overhead. Cocteau's scenario contains many film allusions. In Scene 9, for instance, when the Tennis Champion and Golf Player come to blows, he writes: 'The one who receives them should stoop; the one who delivers them should be carried away by the gesture into nothingness, turning in place, etc. ... (Think of Ch. Chaplin's battles.) Tarts and gigolos shoot movies, take pictures, wind film, keep score, etc. ${ }^{58}$ And in Scene 10, as Perlouse and Beau Gosse move to centre stage for a final embrace, he adds, 'like the end of adventure films'. ${ }^{59}$

References to movies appeared in other ballets as well. Within the Quota, a 1923 Ballets Suédois offering, featured a Mary Pickford type ('The Sweetheart of the World'), who transformed the hero, a Swedish immigrant newly arrived in New York, into a movie star. With a jazzy score by Cole Porter that spoofed the plunkings of movie house accompanists, the ballet poked fun at Hollywood conventions - even as it imitated them. La Pastorale, which Diaghilev produced in 1926, aped such conventions as well. In fact, part of the action - devised by Boris Kochno - actually took place on a movie set. 'The members of a film company arrive to "shoot a scene",' wrote Cyril W. Beaumont in his 'annal' for 1926:

The operators set up their cameras and the producer indicates what is to be done. The Star and two actors go through a scene. ... The telegraph boy awakes and is amazed to find himself alone with the Star. They fall in love and stroll away. The producer and his staff begin an agitated search for the Star. 
... [T] he boy return[s] arm-in-arm with the Star, ... the boy disappears. The members of the film company depart. ${ }^{6 i)}$

With twelve scenes, a large number of rostrums and screens on wheels, the production was not only trite but also unwieldy.

Although Diaghilev toyed with film as a setting and a mimetic device, it was his rival Rolf de Maré who first made it part of the text of a ballet. Premiered in 1924 by the Ballets Suédois, Relâche was an event in the history of avant-garde performance. With a scenario by the painter Francis Picabia, ${ }^{61}$ who designed the remarkable sets, the ballet included a cinematic interlude, Entr'acte, that has since become a film classic. Entr'acte was directed by René Glair, who had made his first on-screen appearance in Loie Fuller's Le Lys de la vie and his debut as a director in 1923 with Paris qui dort. Entr'acte had no story or narrative logic, and its images - a canon dancing a gig, a runaway casket that exploded like a grenade were treated as dynamic events, liberated (in Jacques Bourgeois's phrase) 'from the obligation to convey meaning ${ }^{62}$ The action of the ballet - which included the dancers stripping from formal attire to tights and then dressing again, miming the words to Satie's music for 'The Dog's Tail', and pouring water from one bucket to another - had little obvious connection to the film. Indeed, most of the staged action, a combination of mime and what today would be called 'pedestrian' movement, was the antithesis of Clair's exuberant images and dynamic editing. ${ }^{63}$

In 1928, when film made its belated appearance on the Ballets Russes stage, it was over strong objections from Diaghilev. The result, however, was a deeply poetic work, one that, despite the incoherence of the scenario (by Kochno) and the mediocre music (by Nicolas Nabokov), was transformed by Pavel Tchelitchew's 'phosphorescent kinetics' (in Lincoln Kirstein's phrase) ${ }^{64}$ into a visionary integration of dance and film. In Ode, as Donald Windham later observed, 'it [was] impossible to say ... where the designer's work end[ed] and the choreographer's beg[an]'. ${ }^{65}$

Tchelitchew's scenario, dictated to his technical assistant Pierre Charbonnier, describes the ballet's cinematic effects and equally remarkable lighting effects. Both recall earlier experiments by Loie Fuller and newer ones in 'pure cinema' by film-maker Henri Chomette (René Clair's brother) and the surrealist artist Man Ray. In the third tableau, Tchelitchew writes: 
A diffused sombre blue light is interrupted by the projection of a great hand on the white screen. ... It halts and ... a real box materializes from the screen. The illusive hand continues to descend, and La Nature, stepping forward, receives the box and places it on the ground as the hand fades. She opens it and from it springs (projected in brilliant white on a black screen) a large white oval (a seed) which expands, ... becomes a stem and then a cluster. ... Finally, as the box gives forth more seeds, a luminous tree develops. Magically, to right and left respectively, appear, all at once, a bouquet of flowers and various fruits. ${ }^{36}$

\section{In the sixth tableau, the soloists danced under spotlights, while}

[p]rojected on the screen behind, as if in the midst of flames, is a pagan fete, a sort of bacchanal with nude men and women. The vision and the actual dancers mingle like one scene. The luminous arches, dimmed for the dances, return, becoming cascades. Lights jump about and tremble, multiply and turn into fixed signs of the heavens. Like a fireworks spectacle, stars, balls of fire, lightnings, spirals appear and play about. A general light now turns green, blue, yellow, orange, red in quick succession; at last, a quivering white. In sudden changes, this alternates with red, which finally becomes incredibly bright, like fire, and remains. The background lights have been fading and now are bright, silvery reflections, all pulsating. ${ }^{67}$

\section{Ten years after the premiere, the critic A. V. Coton still remem- bered the ballet vividly:}

One's strongest remaining impression is of the unearthly beauty created in most of the scenes by a revolutionary use of light ...-floods, spots, panoramic effects, projections against a screen and great bursts of light suggesting the sudden animation of pyrotechnical set-pieces, as the groups of dancers and static figures were bathed in pools of glowing illumination, swiftly dimmed and flooded again, almost imperceptibly changing colours ... A projector shot enormous blossoms on to the backcloth whilst figures in the foreground complemented the pattern in a slow-tempo process referential to the opening and unfolding of flowers seen through the agency of the quick-time cinema camera. The final and furthest departure came when a white-clad and masked group danced within a geometric limitation of spaces bounded by cords which were passed from hand to hand, creating an infinite succession of Euclidean forms about which the figures wove a complementary notation of spaceimages, as they joined hands, linked arms, released, extended in slow arabesque and moved silently around this formalized stage-within-a-stage. ${ }^{68}$

In this mystical decor, Massine created his first semi-abstract choreography. By 1927, asserts his biographer Vicente GarcíaMárquez, Massine's interest in abstraction 'had become nearly allabsorbing'. With the painters Sonia and Robert Delaunay, he began work on Perpetomobile, a ballet to Schubert consisting of 'visions of rhythm and colour' or, as Sonia Delaunay put it, 'pure 
dance for the senses and the intellect, without tricks, naked' ${ }^{69}$ The project came to naught. However, in Ode, despite a scenario that was often at cross-purposes with the design, Massine's choreography attained something of this formal 'nakedness' and 'purity'. Felia Doubrovska, who danced one of the female leads, later recalled that except for some of the architectural and geometrical configurations and the role danced by Serge Lifar, the choreography was poetic and classical, emphasising long arabesques, développés, and a formal rhythmic beauty. ${ }^{70}$ The classical line was accentuated by the white leotards and tights worn by the soloists, men and women alike. 'It was the first time,' wrote Alexandra Danilova, who danced the other female lead, 'we didn't wear anything on top of our leotards. ${ }^{\text {, }}$ It is unclear whether this particular idea was Massine's (as he claimed) or Tchelitchew's (as Danilova says), since there is no evidence of how the two collaborated. ${ }^{72}$ That they did work closely together (at least on some sections of the ballet) is clear from Beaumont's description of one of the pas de deux, a kind of elegy

in which the dancers ... [held], each with one upraised hand, a slender, horizontal pole, from the first and last third of which was suspended a length of gauze. ... A number of beautiful effects were achieved when the dancers danced behind the gauze, which invested them with an ectoplastic quality, or else appeared alternately in the open space, so that a solid form danced with a shadowy one. ${ }^{73}$

And a little further on, speaking of the ballet's strange, celestial beauty, Beaumont adds:

Those extraordinary designs, formed of everchanging lines and triangles of cord, suggested animations of the diagrams illustrating Euclid's propositions; and yet always in and out of those corded mazes moved, crouched, leaped, and glided those beautiful unknown forms. ${ }^{74}$

After performances in Paris and London, Ode was dropped from the Ballets Russes repertory. Although British critics like Coton saw the work as prefiguring Massine's symphonic ballets and American critics such as Kirstein as presaging Tchelitchew's creations with Balanchine, none of these later works entailed the use of film. Indeed, within the realm of dance theatre, few designers pursued this avenue of investigation until the advent of post-modernism. In the intervening decades, ballet (and modern dance, for that matter) shied from incorporating film into works conceived for the stage. 


\section{DANGE RESEARGH}

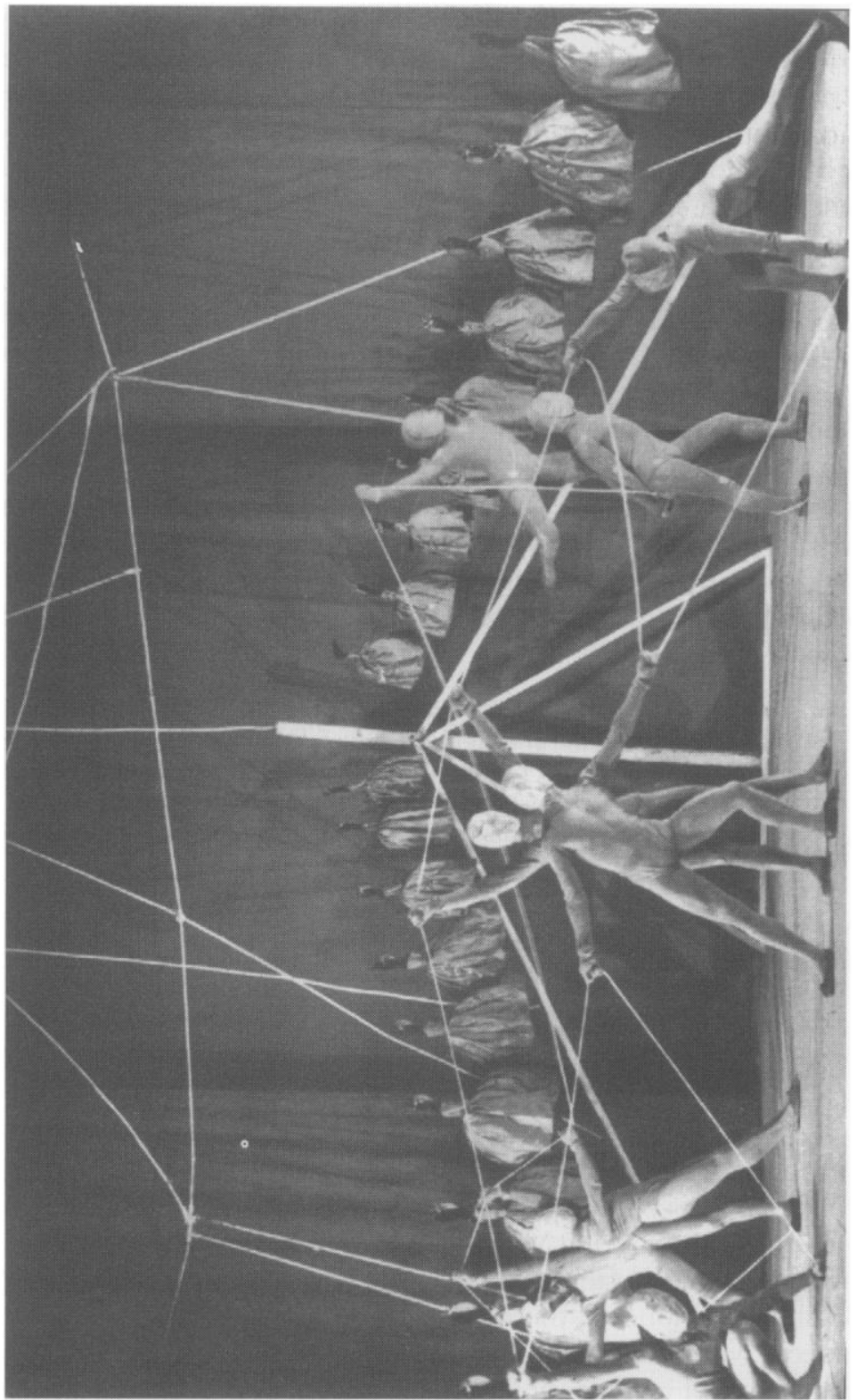

Fig. 4. The Ballets Russes in Ode, choreographed by Léonide Massine and designed by Pavel Tchelitchew (Pritchard Collection) 
This diffidence may well have been prompted by cost: film is an expensive medium. Other possible explanations include the divide between post-Diaghilev ballet and experiments in other media, and, in the United States especially, 'highbrow' mistrust of a medium overwhelmingly identified with mass culture. This lingering disdain almost certainly explains the paucity of films documenting Balanchine's work before the 1970s, even as his years in Hollywood suggest his fascination with a medium that offered the possibility, as he once wrote, of 'free fantasy'. ${ }^{75}$

The Diaghilev era was rich in crossovers between dance and film. Diaghilev was not only aware of them, but also attracted in some measure to their possibilities, especially when they were associated with the avant-garde. However, on every occasion that he undertook a project in which cinematic elements appeared, he chose not to pursue the line of exploration beyond the individual project. In the case of Parade, it is easy to ascribe this failure to the anti-populism that colored all his attitudes. Fireworks and Ode are another matter, however. Both originated in trends within the avant-garde and embodied an experimentalism that was as essential to his art as tradition. Too much so, perhaps: in their embrace of abstraction they entered a territory from which Diaghilev, the traditionalist, felt compelled to retreat. If Diaghilev declined to explore the possibilities opened by his encounters with film, ultimately it was because he could never abjure a notion of high art that the mere existence of the cinema threatened to destroy or countenance a form of theatrical representation that eliminated or dismembered the human figure. Above all, these roads not taken reveal the sway of tradition over Diaghilev's imagination even at its most experimentalist and the limits of his trust in the new.

\section{NOTES}

' 'A Film to Music: "The Sleeping Princess"', The Times, 29 Dec. 1921, p. 6. The article, which was unsigned, was written by the newspaper's film correspondent.

2 'Films Based on Music: An Ambitious Scheme', The Times, 17 Feb. 1922, p. 8.

${ }^{3}$ T. S. Eliot, 'In Memoriam: Marie Lloyd', The Criterion, 1, no. 2 (Jan. 1923), p. 194.

${ }^{4}$ Michel Fokine, 'The New Russian Ballet', The Times, 6 July 1914, p. 6. Fokine's 'letter' is reprinted in Cyril W. Beaumont, Michel Fokine and His Ballets (New York: Dance Horizons, 1981), pp. 144-7.

${ }^{5}$ Michel Fokine, 'The New Ballet', in Beaumont, Michel Fokine, p. 135. This article was originally published in the Russian periodical Argus in 1916. 


\section{DANGE RESEARGH}

${ }^{6}$ Quoted in Valerian Svetloff, Anna Pavlova, trans. A. Grey (Paris, 1922; rpt. New York: Dover, 1974), p. 156.

' Edwin Evans, 'Ballet and Film', The Dancing Times, Feb. 1922, p. 433.

${ }^{8}$ Quoted in Martel Epique, 'New Schools for Old: A Chat on Mime with Mme. Astafieva', Dancing Times, May 1917, p. 244.

${ }^{9}$ Suzanne Carbonneau Levy, 'The Russians are Coming: Russian Dancers in the United States, 1910-1933' (Chapel Hill, N.C.: Duke University Press, forthcoming), pp. 321-2, $443, n$. 104. I am grateful to the author for a copy of the manuscript, which is based on her 1990 doctoral thesis (New York University).

10 For Gorsky and Karalli, see Elizabeth Souritz, 'Isadora Duncan and Prewar Russian Dancemakers,' in The Ballets Russes and Its World, ed. Nancy Van Norman Baer and Lynn Garafola (New Haven, Conn.: Yale University Press, in press).

${ }^{11}$ Agnes de Mille, Dance to the Piper (Boston: Little, Brown, 1951), pp. 45-56. Unlike her uncle, who changed the spelling of his surname to DeMille, Agnes de Mille retained the traditional spelling of the family name.

${ }^{12}$ For an extended discussion of Kosloff's film career, see Carbonneau Levy, The Russians are Coming, pp.137-62.

${ }^{13}$ For a discussion of Fokine's contribution to these works, see Dawn Lille Horwitz, Michel Fokine (Boston: Twayne Publishers, 1985), pp. 41-50.

${ }^{14}$ Agnes de Mille alluded to this in a 1938 letter to her mother. Calling Massine 'the real Cecil de Mille [sic) of the dance', she described a section of his Seventh Symphony: 'When in the allegretto a naked adolescent is brought in crucified and trundled around the stage for twelve minutes while Nini Theilade weeps and caresses him and John the Baptist dressed as Bela Lugosi has epilepsy at his feet, I realized I was watching the thing that Cecil has been waiting all his life to do, or maybe he has done it but in his case for the masses.... Massine will make a fortune out of it. I must see if I can't bring the two together' (quoted in Barbara Barker, 'Agnes de Mille, Liberated Expatriate, and the American Suite, 1938', Dance Chronicle, 19, no. 2 (1996), p. 129 note.

${ }_{15}$ Mikhail Yampolsky, 'Kuleshov's Experiments and the New Anthropology of the Actor', in Inside the Film Factory: New Approaches to Russian and Soviet Cinema, ed. Richard Taylor and Ian Christie (London: Routledge, 1991), p. 46.

${ }^{16}$ Natalia Roslavleva, 'Stanislavsky and the Ballet', introd. Robert Lewis, Dance Perspectives, 23 (1965), p. 23; Souritz, 'Isadora Duncan and Prewar Russian Dancemakers'.

${ }^{17}$ Spencer Golub, Evreinov: The Theatre of Paradox and Transformation (Ann Arbor, Mich.: UMI Research Press, 1984), pp. 110, 127. During the 1910-1911 season, when Presniakov was brought into the company, the actors also studied Dalcroze eurhythmics (ibid., p. 127). ${ }^{18}$ Ibid., pp. 149, 151. Barabanov, who worked by day as a clerk, danced under the stage name Z. F. Ikar. In addition to dancers, his repertory also included impersonations of singers and actresses, such as Sarah Bernhardt.

${ }_{19}$ Elizabeth Souritz, Soviet Choreographers in the 1920s, trans. Lynn Visson, ed. Sally Banes (Durham, N.C.: Duke University Press, 1990), p. 35; Solomon Volkov, St. Petersburg: A Cultural History, trans. Antonina W. Bouis (New York: Free Press, 1995), pp. 190-1; Dearest Babushkin: The Correspondence of Vera and Igor Stravinsky, 1921-1954, with Excerpts from Vera Stravinsky's Diaries, 1922-1971, ed. Robert Craft, trans. Lucia Davidova (New York: Thames and Hudson, 1985), p. 5.

${ }^{20}$ Volynsky is quoted in Souritz, Soviet Choreographers in the 1920s, p. 34; for Karsavina, see John E. Bowlt, 'Constructivism and Russian Stage Design', Performing Arts Fournal, 1, no. 3 (winter 1977), p. 74.

${ }^{21}$ Lasar Galpern, 'Body Training for Actors', Theatre Workshop, Jan.-Mar. 1937, p. 44. In the 1910s, Galpern studied ballet with Nicolas Legat, character dance with the Bolshoi's Lev Lashchilin, body movement for actors with Prince Sergei Volkonsky, and eurhythmics at the Dalcroze Institute, Moscow. After leaving Russia, he danced briefly with Bronislava Nijinska, and in 1926 became the ballet master of the Cologne Opera House, where he 


\section{DANGE, FILM AND THE BALLETS RUSSES}

staged The Rite of Spring four years later. In 1932, he was hired by Roxy to produce ballets for the Radio City Music Hall in New York. He remained in the city, where he directed the American Children's Theatre, taught dramatic art at the Group Theatre, staged The Prodigal Son for the Philadelphia Ballet, presented solo concerts (frequently on 'Hebrew' themes), and worked as a staff choreographer for the WPA Federal Dance Project. In the 1940s he settled in California. For his Rite of Spring and a discussion of his artistic views, see Susan Manning, 'German Rites: A History of Le Sacre du Printemps on the German Stage', Dance Chronicle, 14, nos. 2-3 (1991), pp. 133-5; for a collection of his essays, including 'Body Training for Actors', see Lasar Galpern, Letters on the Theatre and the Dance (New York: Polychrome Corp., 1942).

${ }_{22}$ Bowlt, 'Constructivism and Russian Stage Design', p. 69.

${ }^{23}$ Rumnev was the stage name of Alexander Ziakin, a close childhood friend of Pavel Tchelitchew. As young men, notes Tchelitchew's biographer Parker Tyler, the two 'nursed tendencies toward designing for the stage as well as dancing there' (The Divine Comedy of Pavel Tchelitchew [New York: Fleet Publishing, 1967], p. 182). As a teenager, Tchelitchew had studied privately with Mordkin (p. 183). In his book, Parker reproduces a semi-nude photograph of Rumnev, whose musculature and well-developed instep reveal extensive ballet training.

${ }^{24}$ Dearest Babushkin, p. 5. According to Robert Craft, she was cast as the Bride in Les Noces but was obliged to withdraw because of illness (Igor and Vera Stravinsky: A Photograph Album 1921 to 1971, ed. Robert Craft [New York: Thames and Hudson, 1982], p. 56, n. 58). Given the ballet's neoclassical style and the fact that all the women danced on pointe, it seems highly unlikely that Nijinska would have cast her in the part. In any event, this is the only source in the considerable memoir literature about the ballet that mentions Vera as rehearsing the role.

${ }^{25}$ Quoted in Konstantin Rudnitsky, Russian and Soviet Theater 1905-1932, trans. Roxane Permar, ed. Lesley Milne (New York: Abrams, 1988), p. 17.

${ }^{26}$ Ibid.

${ }^{27}$ Ibid., p. 18.

${ }^{28}$ John E. Bowlt, Russian Stage Design: Scenic Innovation 1900-1930 (Jackson, Miss.: Mississippi Museum of Art, 1982), p. 131.

${ }^{29}$ For their collaboration, see Nancy van Norman Baer, Bronislava Nijinska: A Dancer's Legacy (San Francisco: Fine Arts Museums of San Francisco, 1986), pp. 18-21, 49-53. It is worth noting that Exter was only one of several Russian designers, including Boris Bilinsky, Yury Annenkov, and Alexandre Benois (who headed the design team for Abel Gance's Napoléon), who worked in ballet, drama, and film during the interwar years. The subject certainly deserves an in-depth investigation.

${ }^{30}$ For some of these connections, see my Diaghilev's Ballets Russes (New York: Oxford University Press, 1989), pp. 29-32 (Carnaval and Petrushka), 53-5 (L'Après-midi d'un Faune), 70-1 (Le Sacre du Printemps), and 73-4 (Till Eulenspiegel).

${ }^{31}$ Rudnitsky, Russian and Soviet Theater, p. 94.

${ }^{32}$ Sergei M. Eisenstein, Immoral Memories: An Autobiography, trans. Herbert Marshall (Boston: Houghton Mifflin, 1983), p. 46.

${ }^{33}$ Quoted in Yampolsky, 'Kuleshov's Experiments and the New Anthropology of the Actor', p. 48. For Volkonsky's ideas and their dissemination, see pp. 32-7; for Kuleshov's montage experiments involving dance, pp. 45-6; for the Experimental Heroic Theatre, pp. $46-7$.

${ }^{34}$ Serge Diaghilev, telegram to Igor Stravinsky [Jan. 1915], in Stravinsky: Selected Correspondence, ed. Robert Craft, II (New York: Knopf, 1984), p. 17.

${ }^{35}$ Depero, in fact, received two commissions: to design the sets and costumes of Le Chant du Rossignol, scheduled for production in spring 1917, and the horse in 'Bova Korolevitch and the Swan Princess', the second episode of Contes Russes, which premiered in 1917. For whatever reason, Diaghilev decided against using Depero's designs for Le Chant du Rossignol, 


\section{DANGE RESEARGH}

which came to the stage in 1920 with designs by Matisse. Depero's horse suffered a similar fate. As Massine recalled in his memoirs: 'The question of what to do about the knight's horse caused us much perplexity. Diaghilev had commissioned the futurist artist Fortunato Depero to design something suitable, and eventually we were summoned to his studio on the outskirts of Rome. As we walked into the room the artist pointed proudly to his construction - a bulbous outsized elephant! We stood staring at it silently for a few moments until Diaghilev, in a sudden outburst of rage, smashed the papier-mâché animal with his walking stick' (My Life in Ballet, ed. Phyllis Hartnoll and Robert Rubens [London: Macmillan, 1968], p. 99).

${ }^{36}$ Fortunato Depero, 'Notes on the Theatre', in Michael Kirby and Victoria Nes Kirby, Futurist Performance (New York: PAJ Publications, 1986), p. 209.

${ }^{37}$ Marinetti et al., 'The Futurist Cinema', ibid., pp. 212, 213-4, 216. Another futurist film that Diaghilev may have seen and certainly knew about was Drama v kabare futuristov No. 13 (Drama in the Futurists' Cabaret No. 13), directed by Vladimir Kasyanov and released in January 1914. The film starred Natalia Goncharova and Mikhail Larionov, artists who formed the nucleus of Diaghilev's wartime creative circle, and included a 'futurist tango' as well as a tap dance, the latter performed by Goncharova. For a description, see Anthony Parton, Mikhail Larionov and the Russian Avant-Garde (London: Thames and Hudson, 1993), pp. 71-3.

${ }_{38}$ Leonide Massine, 'On Choreography and a New School of Dancing', Drama, 1, no. 3 (Dec. 1919), p. 69. Another ballet choreographed during the months in Rome that employed simultaneity, although less successfully than Ladies, was the Baba-Yaga episode of Contes Russes. 'In working out [the] finale,' wrote Massine in his memoirs, 'I allowed my imagination to run away with me and created such a variety of simultaneous movements, with the principal characters weaving to and fro among the corps de ballet, that each group overshadowed the next and it was impossible to see any of the movements clearly. The scene was so lacking in artistic coherence that instead of an exciting conclusion it was nothing but a frenzy of disconnected activity' (My Life in Ballet, ed. Phyllis Hartnoll and Robert Rubens [London: Macmillan, 1968], pp. 100-101).

${ }^{39}$ Cyril W. Beaumont, Complete Book of Ballets (London: Putnam, 1937), p. 844.

${ }^{40}$ Quoted in Vicente García-Márquez, Massine: A Biography (New York: Knopf, 1995), p. 398 , n. 16.

${ }_{41}$ Maurizio Fagiolo dell'Arco, 'Balla's Prophecies', Art International, 12, no. 6 (Summer 1968), p. 67.

${ }^{42}$ Henri Quittard, 'Les Concerts', Figaro, 9 May 1914, p. 5.

${ }^{43}$ Quoted in Giovanni Lista, Loie Fuller: danseuse de la Belle Epoque (Paris: Stock-Editions d'Art Somogy, 1994), p. 500.

${ }^{44}$ Depero, 'Notes on the Theatre', p. 207.

${ }^{45}$ Lista, Loie Fuller, p. 643, n. 39.

${ }^{46}$ Bronislava Nijinska, 'Reflections About the Production of Les Biches and Hamlet in Markova-Dolin Ballets', trans. Lydia Lopokova, The Dancing Times, Feb. 1937, p. 617.

${ }^{47}$ Francis Steegmuller, Cocteau: A Biography (Boston: Little, Brown, 1970), p. 201.

${ }^{48}$ Jean Cocteau, Carte Blanche (Paris: Mermod, [1952]), p. 201. For Diaghilev's regard for Chaplin, see Richard Buckle, Diaghilev (London: Weidenfeld and Nicolson, 1979), p. 316.

${ }^{49}$ Quoted in Frank W. D. Ries, The Dance Theatre of Jean Cocteau (Ann Arbor, Mich.: UMI Research Press, 1986), p. 40. For Chung Ling Soo, see Deborah Menaker Rothschild, Picasso's 'Parade': From Street to Stage, foreword Jeanne Thayer and Michael Iovenko (New York: Sotheby's Publications, 1991), pp. 76-9, 91-5.

${ }^{50}$ Cocteau uses the phrase in the preface of -Les Mariés de la Tour Eiffel. See Jean Cocteau, The Infernal Machine and Other Plays (New York: New Directions, 1963), p. 153. The translation is by Dudley Fitts.

${ }^{51}$ Carte Blanche, p. 149.

${ }^{52}$ Massine, My Life in Ballet, p. 104. 


\section{DANGE, FILM AND THE BALLETS RUSSES}

${ }^{3}$ R. J., 'La Danse et le cinéma au ralenti', La Danse, May 1922, n.p.

'Theodore Curzon, 'Film Dancing', The Dancing Times, Sept. 1919, p. 563.

'5 'Paris Notes', The Dancing Times, Aug. 1922, p. 935.

'La Danse à travers le monde', La Danse, Sept. 1921, n.p.

"Lista, Loie Fuller, p. 535. Although filmed in 1920, Le Lys de la vie had its first public screening only in March 1921 (ibid., p. 643).

${ }_{58}$ The libretto of $L e$ Train Bleu is reproduced in Erik Aschengreen, Fean Cocteau and the Dance, trans. Patricia McAndrew and Per Avsum (Copenhagen: Gyldendal, 1986), Appendix 5. Scene 9 appears on p. 272.

${ }^{59}$ Ibid., p. 273.

6in Cyril W. Beaumont, Bookseller at the Ballet (London: C. W. Beaumont, 1975), pp. 345-6.

6) The ballet was actually conceived by the poet Blaise Cendrars, who wrote the original scenario. However, after he left for Brazil, it was turned over to Picabia to 'embroider'. Although traces of the original scenario remained in the ballet, Cendrars himself ceased to figure in the production. For a discussion of Cendrars's contribution, see Miriam Cendrars, 'Les Métamorphoses parisiennes d'un ballet suédois', Continent Cendrars, 1 (1986), pp. 12-23. 62. Jacques Bourgeois, René Clair (Paris: Roulet, [1949]), p. 28.

${ }_{63}$ For a description of the staged action, see William Canfield, 'Dada Experiment: Francis Picabia and the Creation of Relâche', in Paris Modern: The Swedish Ballet 1920-1925, ed. Nancy Van Norman Baer (San Francisco: Fine Arts Museums of San Francisco, 1995), p. 132.

${ }^{6 t}$ Lincoln Kirstein, Tchelitchev (Santa Fe, N.M.: Twelvetrees Press, 1994), p. 28.

is. Donald Windham, 'The Stage and Ballet Designs of Pavel Tchelitchw', Dance Index, 3, nos. 1-2 (Jan.-Feb. 1944), p. 9.

${ }^{66}$ Quoted in Tyler, The Divine Comedy of Pavel Tchelitchew, p. 331.

67 Ibid., p. 333.

A. V. Coton, A Prejudice for Ballet (London: Methuen, 1938), pp. 86-7.

${ }^{69}$ Quoted in García-Márquez, Massine, p. 199.

${ }^{70}$ Ibid., p. 201.

${ }^{71}$ Alexandra Danilova, Choura: The Memoirs of Alexandra Danilova (New York: Knopf, 1986), p. 93.

${ }_{72}$ Massine, My Life in Ballet, p. 174; Danilova, Choura, p. 93. Although Tchelitchew's scenario, as quoted in Tyler's The Divine Comedy of Pavel Tchelitchere, does mention leotards, this may be the author's own rendering of a less precise term in the original French. Massine makes only brief mention of Tchelitchew, crediting him with the 'row of puppets in period costume' that formed the background of one of the scenes and with the 'irregular framework of white cords ... used to enclose the action' (My Life, p. 174). Tyler, in a chapter replete with unascribed conversations, simply identifies Massine as the ballet's choreographer (Divine Comedy, p. 330). Nicolas Nabokov, the ballet's composer, is also silent on the subject, merely saying that when he arrived in Monte Carlo he was told by Boris Kochno that 'Tchelitchew had invented marvelous sets for Ode' and that 'Massine liked them' (Bagázh: Memoirs of a Russian Cosmopolitan [New York: Atheneum, 1975], p. 153).

Beaumont, Bookseller at the Ballet, p. 383.

"Ibid.

${ }^{75}$ George Balanchine, 'Ballet in Motion Pictures', in Anatole Chujoy and P. W. Manchester, eds., The Dance Encyclopedia, rev. ed. (New York: Simon and Schuster, 1967), p. 646. 